\title{
A Double-Blind, Randomized, Placebo-Controlled Study on the Evaluation of the Efficacy of Vaginal Misoprostol Plus Intramuscular Diclofenac Sodium in to Ease Insertion of Intra Uterine Contraceptive Device in Stenosis Cervix
}

\author{
MOHAMED EL-HUSSENY RADWAN, M.D. \\ The Department of Obstetrics \& Gynecology, Faculty of Medicine, Zagazig University, Zagazig 44519, Egypt
}

\begin{abstract}
Background: Intrauterine contraceptives (IUCs) are one of the most powerful contraceptives. The most popular versions used worldwide are the Cut $380 \mathrm{~A}$ vice (Cu-IUD) and the levonorgestrel-releasing intrauterine system (LNG-IUS). Both forms are safe, cost-effective in the long run.

Aim of Study: The aim of this study was to evaluate the efficacy of combination of vaginal misoprostol with intramuscular diclofenac sodium in decreasing pain and facilitating IUD insertion in women with cervical stenosis.

Patients and Methods: The patients were randomized to four groups (32 patient each) using simple randomization (closed envelop) and classified into: The first group (Misoprostol Group): Includes 32 patients who received two tablets (400mg) of misoprostol in the posterior fornix of the vagina 2 hours before IUD insertion. The second group (Diclofenac Group): Includes 32 patients who received diclofenac sodium $75 \mathrm{mg}$ ampule intramusculary 2 hours before IUD insertion. The third group (Misoprostol Diclofenac Group): Includes 32 patients who received two tablets $(400 \mathrm{mg}$ ) of misoprostol in the posterior fornix of the vagina and diclofenac sodium $75 \mathrm{mg}$ ampule intramusculary 2 hours before IUD insertion. The fourth group (placebo Group): Includes 32 patients who received placebo.
\end{abstract}

Result: Misoprostol group and misoprostol diclofenac group showed a significant higher number of easy IUD insertion, and misoprostol diclofenac group showed a significant lower extremely difficult insertion in comparison to other groups. There was statistically significant difference between misoprostol diclofenac and placebo groups as regard pain.

Conclusion: The administration of vaginal misoprostol and intramuscular diclofenac sodium before IUCD insertion in women with cervical stenosis facilitate the IUCD insertion, decrease failure of insertion and reduce pain sensation during IUCD insertion.

Key Words: IUCD - Misoprostol - Diclofenac sodium stensosed Cervix.

Correspondence to: Dr. Mohamed El-Husseny Radwan, E-Mail: hussenyradwan@gmail.com,

\section{Introduction}

THE intrauterine implant (IUD) and also known as the intrauterine contraceptive device (IUCD) is a thin, often T-shaped birth control device that is implanted in a woman's uterus to prevent pregnancy. IUDs are a type of long acting reversible birth control (LARC) [1]

Cervical stenosis is a narrowing of the pathway through the cervix or is completely closed. It is known to be a cause associated with difficult sounding of the cervical canal or even inability to implant IUD [2].

Mechanical ways to resolve anatomical cervical stenosis and scarring during IUD injection by capturing the cervix with the tenaculum and the additional use of the dilator. This methodsare usually associated with increased anxiety, pain, or even failure [3].

Misoprostol is a low-cost E1 prostaglandin derivative that has minimal side effects and is an important tool for the management of premature and missed abortions, the prevention and treatment of postpartum haemorrhage and the induction of provocative abortion, as well as labour induction. Several trials have demonstrated the value of misoprostol as a cervical maturation agent in nonpregnant women [4].

Diclofenac sodium is a nonsteroidal agent with pronounced analgesic and anti-inflammatory effects. It is a prostaglandin synthetase inhibitor. It has been used in obstetrics and gynaecology to manage acute and chronic postoperative pain, menstrual pain, surgical termination pain, menorrhagia and preterm birth tocolytics [5] . 


\section{Patients and Methods}

The study was carried out on 128 women with cervical stenosis and candidate for $\mathrm{Cu} \mathrm{T} 380 \mathrm{~A}$ IUCD insertion were participated in the study came to family planning clinic in Obstetrics and Gynecology Department in Zagazig University Hospitals during the period from December 2018 to November 2020 .

\section{Inclusion criteria:}

1 - Women above 18 years of age.

2- Declared their wish for insertion of an IUCD.

3- They have already cervical stenosis or had a history of cervical stenosis, such as delivery by cesarean section, history of cervical surgical manipulation and inflammation of the cervix.

\section{Exclusion criteria:}

1- Positive pregnancy test.

2- Pelvic inflammatory disease or active cervical infection.

3- Allergy to misoprostol or diclofenac sodium.

4- Uterine or cervical anomaly.

5- Cervical or uterine fibroid.

6- Unexplained vaginal bleeding.

7- Suggested gynecologic malignancy.

All patients submitted to the study were counseled thoroughly about the procedure including its values and hazards, and the aim of the study. After this, a written consent was obtained and signed by the patient.

\section{Classification:}

The patients were randomized to four groups (32 patient each) using simple randomization (closed envelop) and classified into: The first group (Misoprostol Group): Includes 32 patients who received two tablets $(400 \mathrm{mg})$ of misoprostol in the posterior fornix of the vagina 2 hours before IUD insertion. The second group (Diclofenac Group): Includes 32 patients who received diclofenac sodium $75 \mathrm{mg}$ ampule intramusculary 2 hours before IUD insertion. The third group (Misoprostol Diclofenac Group): Includes 32 patients who received two tablets $(400 \mathrm{mg}$ ) of misoprostol in the posterior fornix of the vagina and diclofenac sodium $75 \mathrm{mg}$ ampule intramusculary 2 hours before IUD insertion. The fourth group (placebo Group): Includes 32 patients who received placebo.

\section{Methods:}

All patients were submitted to:

Complete history taking.
Full Examination:

IUD insertion protocol:

Pelvic Ultrasound is done to evaluate uterus and adnexa.

Insertion of $\mathrm{Cu}$ T 380A IUD:

1- Wear asuitable sterile gloves.

2- Insert largest speculum for maximum cervical exposure.

3- Cleanse the cervix with povidone iodine or other antiseptic.

4- Using sterile gloves, withdraw the IUD into the cannula per system directions.

5- Apply the tenaculum to stabilize the cervix.

6- Gently sound the uterus.

7- Insert the IUD into the uterine cavity.

8- Cut strings to appropriate length [6,7]

\section{The outcome measures:}

a- The primary outcome measures of this study were the proportion of failed IUCD insertion regardless the reason.

The degree of difficulty of IUCD insertion judged as the resistance of the internal os, dividing the degree of difficulty of insertion extremely easy, easy, moderate, difficult, and extremely difficult.

b- The secondary outcomes were the side effects of IUCD insertion like vasovagal reaction (nausea and vomiting), syncobal attack, bleeding and perforation.

\section{Results}

This was randomized double-blind controlled trial carried out on 128 women with cervical stenosis and candidate for $\mathrm{Cu} \mathrm{T}$ 380A IUCD insertion were participated in the study came to family planning clinic in Obstetrics and Gynecology Department in Zagazig University Hospitals during the period from December 2018 to November 2020.

Table (1) shows that there was no statistically significant difference between groups according to success of Age or BMI.

Table (2) shows that there was no statistically significant difference between groups according to success of gravidity. There was no statistically significant difference between groups according to success of Previous Mode of delivery or History of Genital infection. There was no statistically significant difference between groups according to the timing of the last delivery (years). 
Table (3) shows statistically significant difference between groups according to the need to cervical dilatation and according to success of insertion.

Table (4) shows that there was statistically significant difference between (misoprostol diclofenac and placebo) and (Misoprostol and Placebo) groups as regard difficulty of IUD insertion.
Table (5) shows that there was no statistically significant difference between the studied groups as regard pain. There was statistically significant difference between misoprostol diclofenac and placebo groups as regard pain.

Table (6) shows that there was statistically significant difference between the 4 studied groups as regard side effects of IUD insertion.

Table (1): Comparison between the different studied groups according to demographic data.

\begin{tabular}{|c|c|c|c|c|c|c|}
\hline & $\begin{array}{l}\text { Misoprostol } \\
(\mathrm{n}=32)\end{array}$ & $\begin{array}{l}\text { Diclofenac } \\
\quad(\mathrm{n}=32)\end{array}$ & $\begin{array}{l}\text { Misoprostol diclofenac } \\
(\mathrm{n}=32)\end{array}$ & $\begin{array}{l}\text { Placebo } \\
(\mathrm{n}=32)\end{array}$ & $\mathrm{F}$ & $p$ \\
\hline \multicolumn{7}{|l|}{ Age (years): } \\
\hline Min. - Max. & $18.0-38.0$ & $19.0-39.0$ & $18.0-38.0$ & $19.0-33.0$ & 0.047 & 0.986 \\
\hline Mean \pm SD. & $26.63 \pm 6.08$ & $26.0 \pm 6.44$ & $26.37 \pm 6.14$ & $26.61 \pm 4.0$ & & \\
\hline Median (IQR) & $26.0(21.0-30.5)$ & $24.0(21.0-29.0)$ & $27.0(21.0-30.5)$ & $27.50(24.0-29.0)$ & & \\
\hline \multicolumn{7}{|l|}{$B M I\left(\mathrm{~kg} / \mathrm{m}^{2}\right):$} \\
\hline Min. - Max. & $21.40-33.80$ & $20.80-34.0$ & $20.30-33.70$ & $20.20-34.20$ & 0.161 & 0.922 \\
\hline Mean \pm SD & $27.19 \pm 3.86$ & $26.32 \pm 3.58$ & $26.60 \pm 3.92$ & $26.70 \pm 4.34$ & & \\
\hline Median (IQR) & $27.80(23.7-29.9)$ & $25.80(23.7-29.0)$ & $27.40(23.3-29.5)$ & $26.80(22.9-30.5)$ & & \\
\hline
\end{tabular}

Table (2): Comparison between the different studied groups according to gravidity, previous mode of delivery, history of genital infection and the time of the last delivery (years).

\begin{tabular}{|c|c|c|c|c|c|c|c|c|c|c|}
\hline \multirow[t]{2}{*}{ Gravidity } & \multicolumn{2}{|c|}{$\begin{array}{l}\text { Misoprostol } \\
\quad(n=32)\end{array}$} & \multicolumn{2}{|c|}{$\begin{array}{l}\text { Diclofenac } \\
\quad(n=32)\end{array}$} & \multicolumn{2}{|c|}{$\begin{array}{l}\text { Misoprostol } \\
\text { diclofenac } \\
(n=32)\end{array}$} & \multicolumn{2}{|c|}{$\begin{array}{c}\text { Placebo } \\
(n=32)\end{array}$} & \multirow[t]{2}{*}{$\begin{array}{l}\text { Test of } \\
\text { sig. }\end{array}$} & \multirow[t]{2}{*}{$p$} \\
\hline & No. & $\%$ & No. & $\%$ & No. & $\%$ & No. & $\%$ & & \\
\hline $\begin{array}{l}1 \\
2 \\
>2\end{array}$ & $\begin{array}{l}10 \\
12 \\
10\end{array}$ & $\begin{array}{l}31.3 \\
37.5 \\
31.3\end{array}$ & $\begin{array}{l}12 \\
12 \\
8\end{array}$ & $\begin{array}{l}37.5 \\
37.5 \\
25.0\end{array}$ & $\begin{array}{l}12 \\
10 \\
10\end{array}$ & $\begin{array}{l}37.5 \\
31.3 \\
31.3\end{array}$ & $\begin{array}{l}10 \\
10 \\
12\end{array}$ & $\begin{array}{l}31.3 \\
31.3 \\
37.5\end{array}$ & $\begin{array}{l}\chi^{2}= \\
0.763\end{array}$ & 0.993 \\
\hline \multirow[t]{3}{*}{$\begin{array}{l}\text { Min. - Max. } \\
\text { Mean } \pm \text { SD. } \\
\text { Median (IQR) }\end{array}$} & \multicolumn{2}{|c|}{$\begin{array}{c}1.0-4.0 \\
2.16 \pm 1.07 \\
2.0(1.0-3.0)\end{array}$} & \multicolumn{2}{|c|}{$\begin{array}{c}1.0-4.0 \\
2.17 \pm 1.15 \\
2.0(1.0-3.0)\end{array}$} & \multicolumn{2}{|c|}{$\begin{array}{c}1.0-4.0 \\
2.16 \pm 1.17 \\
2.0(1.0-3.0)\end{array}$} & \multicolumn{2}{|c|}{$\begin{array}{c}1.0-4.0 \\
2.22 \pm 1.0 \\
2.0(1.0-3.0)\end{array}$} & $\begin{array}{l}\mathrm{H}= \\
0.152\end{array}$ & 0.985 \\
\hline & \multicolumn{2}{|c|}{$\begin{array}{l}\text { Misoprostol } \\
\quad(n=32)\end{array}$} & \multicolumn{2}{|c|}{$\begin{array}{l}\text { Diclofenac } \\
\qquad(n=32)\end{array}$} & \multicolumn{2}{|c|}{$\begin{array}{l}\text { Misoprostol } \\
\text { diclofenac } \\
(n=32)\end{array}$} & \multicolumn{2}{|c|}{$\begin{array}{c}\text { Placebo } \\
(n=32)\end{array}$} & $\chi^{2}$ & $p$ \\
\hline & No. & $\%$ & No. & $\%$ & No. & $\%$ & No. & $\%$ & & \\
\hline \multicolumn{11}{|c|}{ Previous Mode of delivery: } \\
\hline NVD & 4 & 12.5 & 6 & 18.7 & 4 & 12.5 & 4 & 12.5 & 0.387 & $\mathrm{MCp}=$ \\
\hline CS & 28 & 87.5 & 26 & 81.3 & 28 & 87.5 & 28 & 87.5 & & 0.942 \\
\hline \multicolumn{11}{|c|}{ History of Genital infection: } \\
\hline No & 14 & 43.7 & 18 & 56.3 & 12 & 37.5 & 16 & 50.0 & 1.255 & 0.739 \\
\hline Yes & 18 & 56.3 & 14 & 43.7 & 20 & 62.5 & 16 & 50.0 & & \\
\hline Last Delivery (years) & \multicolumn{2}{|c|}{$\begin{array}{l}\text { Misoprostol } \\
\quad(n=32)\end{array}$} & \multicolumn{2}{|c|}{$\begin{array}{l}\text { Diclofenac } \\
\quad(n=32)\end{array}$} & \multicolumn{2}{|c|}{$\begin{array}{c}\text { Misoprostol } \\
\text { diclofenac } \\
(n=32)\end{array}$} & \multicolumn{2}{|c|}{$\begin{array}{c}\text { Placebo } \\
(n=32)\end{array}$} & $\mathrm{F}$ & $p$ \\
\hline Min. - Max. & \multirow{2}{*}{\multicolumn{2}{|c|}{$\begin{array}{l}0.3-18 \\
6.63 \pm 2.11\end{array}$}} & \multirow{2}{*}{\multicolumn{2}{|c|}{$\begin{array}{l}0.2-18 \\
6.46 \pm 2.26\end{array}$}} & \multirow{2}{*}{\multicolumn{2}{|c|}{$\begin{array}{l}0.5-18.5 \\
6.75 \pm 2.33\end{array}$}} & \multirow{2}{*}{\multicolumn{2}{|c|}{$\begin{array}{l}0.2-19 \\
6.59 \pm 2.10\end{array}$}} & 0.054 & 0.983 \\
\hline Mean \pm SD & & & & & & & & & & \\
\hline
\end{tabular}


Table (3): Comparison between groups according to the need to cervical dilatation and according to the success of insertion.

\begin{tabular}{|c|c|c|c|c|c|c|c|c|c|c|}
\hline & \multicolumn{2}{|c|}{$\begin{array}{l}\text { Misoprostol } \\
\quad(\mathrm{n}=32)\end{array}$} & \multicolumn{2}{|c|}{$\begin{array}{l}\text { Diclofenac } \\
\quad(n=32)\end{array}$} & \multicolumn{2}{|c|}{$\begin{array}{c}\text { Misoprostol } \\
\text { diclofenac } \\
(n=32)\end{array}$} & \multicolumn{2}{|c|}{$\begin{array}{c}\text { Placebo } \\
(\mathrm{n}=32)\end{array}$} & \multirow[t]{2}{*}{$x^{2}$} & \multirow[t]{2}{*}{$p$} \\
\hline & No. & $\%$ & No. & $\%$ & No. & $\%$ & No. & $\%$ & & \\
\hline \multicolumn{11}{|c|}{ Need to dilatation: } \\
\hline Negative & 14 & 43.7 & 10 & 31.3 & 16 & 50.0 & 2 & 6.3 & 8.151 & $0.0430^{*}$ \\
\hline Positive & 18 & 56.3 & 22 & 68.7 & 16 & 50.0 & 30 & 93.7 & & \\
\hline Total & 32 & 100 & 32 & 100 & 32 & 100 & 32 & 100 & & \\
\hline \multicolumn{11}{|c|}{ Success of introduction: } \\
\hline Negative & 4 & 12.5 & 10 & 31.3 & 2 & 6.3 & 16 & 50 & 10 & 0.0185 \\
\hline Positive & 28 & 87.5 & 22 & 68.7 & 30 & 93.7 & 16 & 50 & & \\
\hline Total & 32 & 100 & 32 & 100 & 32 & 100 & 32 & 100 & & \\
\hline
\end{tabular}

$\chi 2$ is for chi square test, $p$-value is significant if $<0.05$.

Table (4): Comparison between the different studied groups according to difficulty of IUD insertion.

\begin{tabular}{|c|c|c|c|c|c|c|c|c|c|c|}
\hline \multirow[t]{2}{*}{$\begin{array}{l}\text { Difficulty of } \\
\text { IUD insertion }\end{array}$} & \multicolumn{2}{|c|}{$\begin{array}{l}\text { Misoprostol } \\
\quad(n=32)\end{array}$} & \multicolumn{2}{|c|}{$\begin{array}{l}\text { Diclofenac } \\
\qquad(\mathrm{n}=32)\end{array}$} & \multicolumn{2}{|c|}{$\begin{array}{l}\text { Misoprostol } \\
\text { diclofenac } \\
(n=32)\end{array}$} & \multicolumn{2}{|c|}{$\begin{array}{l}\text { Placebo } \\
(n=32)\end{array}$} & \multirow[t]{2}{*}{$x^{2}$} & \multirow[t]{2}{*}{$p$} \\
\hline & No. & $\%$ & No. & $\%$ & No. & $\%$ & No. & $\%$ & & \\
\hline Easy & 12 & 37.5 & 2 & 6.3 & 12 & 37.5 & 2 & 6.3 & 19.81 & 0.07078 \\
\hline Extremely easy & 4 & 12.5 & 2 & 6.3 & 4 & 12.5 & 2 & 6.3 & & \\
\hline Moderate & 12 & 37.5 & 14 & 43.7 & 14 & 43.7 & 8 & 25.0 & & \\
\hline Difficult & 2 & 6.3 & 8 & 25.0 & 2 & 6.3 & 12 & 37.5 & & \\
\hline Extremely difficult & 2 & 6.3 & 6 & 18.7 & 0 & 0.0 & 8 & 25.0 & & \\
\hline Sig.bet.grps & \multicolumn{10}{|c|}{$\begin{array}{l}\mathrm{MC}_{p_{1}}=0.147, \mathrm{MC}_{p_{2}}=0.898, \mathrm{MC}_{p_{3}}=0.0463, \mathrm{MC}_{p_{4}}=0.0689, \mathrm{MC}_{p_{5}}=0.851 \\
\mathrm{MC}_{p_{6}}=0.0153 *\end{array}$} \\
\hline
\end{tabular}

$\chi^{2}$ : Chi square test MC: Monte Carlo.

$p: p$-value for comparing between the studied groups.

p1: $p$-value for comparing between misoprostol and diclofenac.

p2: $p$-value for comparing between misoprostol and misoprostol diclofenac.

p3: $p$-value for comparing between misoprostol and placebo.

4: $p$-value for comparing between diclofenac and misoprostol diclofenac.

p5: $p$-value for comparing between diclofenac and placebo.

6: $p$-value for comparing between misoprostol diclofenac and placebo.

*: Statistically significant at $p \leq 0.05$.

Table (5): Comparison between the different studied groups according to pain.

\begin{tabular}{|c|c|c|c|c|c|c|c|c|c|c|}
\hline \multirow[t]{2}{*}{ Pain } & \multicolumn{2}{|c|}{$\begin{array}{l}\text { Misoprostol } \\
\quad(n=32)\end{array}$} & \multicolumn{2}{|c|}{$\begin{array}{l}\text { Diclofenac } \\
\quad(n=32)\end{array}$} & \multicolumn{2}{|c|}{$\begin{array}{l}\text { Misoprostol } \\
\text { diclofenac } \\
(n=32)\end{array}$} & \multicolumn{2}{|c|}{$\begin{array}{c}\text { Placebo } \\
(n=32)\end{array}$} & \multirow[t]{2}{*}{$x^{2}$} & \multirow[t]{2}{*}{$p$} \\
\hline & No. & $\%$ & No. & $\%$ & No. & $\%$ & No. & $\%$ & & \\
\hline No & 6 & 18.7 & 12 & 37.5 & 10 & 31.3 & 2 & 6.3 & 12.96 & 0.1646 \\
\hline Mild & 12 & 37.5 & 8 & 25.0 & 10 & 31.3 & 4 & 12.5 & & \\
\hline Moderate & 8 & 25.0 & 10 & 31.7 & 8 & 25.0 & 12 & 37.5 & & \\
\hline High & 6 & 18.7 & 2 & 6.3 & 4 & 12.5 & 14 & 43.7 & & \\
\hline Sig.bet.grps & \multicolumn{8}{|c|}{$\begin{array}{l}\mathrm{MC}_{p_{1}}=0.147, \mathrm{MC}_{p_{2}}=0.898, \mathrm{MCp}_{3}=0.0463, \mathrm{MC}_{p_{4}}=0.0689, \mathrm{MC}_{p_{5}}=0.851 \\
\mathrm{MC}_{p_{6}}=0.0153 *\end{array}$} & & \\
\hline
\end{tabular}

$\chi^{2}$ : Chi square test

MC: Monte Carlo.

$p$ : $p$-value for comparing between the studied groups.

p1: $p$-value for comparing between misoprostol and diclofenac.

p2: $p$-value for comparing between misoprostol and misoprostol diclofenac.

p3: $p$-value for comparing between misoprostol and placebo.

4: $p$-value for comparing between diclofenac and misoprostol diclofenac.

p5: $p$-value for comparing between diclofenac and placebo.

p6: $p$-value for comparing between misoprostol diclofenac and placebo.

*: Statistically significant at $p \leq 0.05$. 
Table (6): Comparison between the different studied groups according to the side effects of IUD insertion in both groups.

\begin{tabular}{|c|c|c|c|c|c|c|c|c|c|c|}
\hline \multirow{2}{*}{$\begin{array}{l}\text { The side effects of } \\
\text { IUD insertion in } \\
\text { both groups }\end{array}$} & \multicolumn{2}{|c|}{$\begin{array}{l}\text { Misoprostol } \\
\qquad(\mathrm{n}=32)\end{array}$} & \multicolumn{2}{|c|}{$\begin{array}{l}\text { Diclofenac } \\
\qquad(\mathrm{n}=32)\end{array}$} & \multicolumn{2}{|c|}{$\begin{array}{c}\text { Misoprostol } \\
\text { diclofenac } \\
(n=32)\end{array}$} & \multicolumn{2}{|c|}{$\begin{array}{c}\text { Placebo } \\
(\mathrm{n}=32)\end{array}$} & \multirow[t]{2}{*}{$x^{2}$} & \multirow[t]{2}{*}{$p$} \\
\hline & No. & $\%$ & No. & $\%$ & No. & $\%$ & No. & $\%$ & & \\
\hline Non & 18 & 56.3 & 26 & 81.3 & 20 & 62.5 & 32 & 100.0 & 20.9 & 0.013 \\
\hline Syncobal attack & 2 & 6.3 & 0 & 0.0 & 2 & 6.3 & 0 & 0.0 & & \\
\hline Gastritis & 0 & 0.0 & 6 & 18.7 & 4 & 12.5 & 0 & 0.0 & & \\
\hline Nausea \& vomiting & 12 & 37.5 & 0 & 0.0 & 6 & 18.7 & 0 & 0.0 & & \\
\hline Sig.bet.grps & \multicolumn{10}{|c|}{$\begin{array}{l}\mathrm{MC}_{p_{1}}=0.0133^{*}, \mathrm{MC}_{p_{2}}=0.383, \mathrm{MC}_{p_{3}}=0.0113^{*}, \mathrm{MC}_{p_{4}}=0.204, \mathrm{FE}_{p_{5}}=0.0688 \\
\mathrm{MC}_{p_{6}}=0.061\end{array}$} \\
\hline
\end{tabular}

$\mathrm{X}^{2}$ : Chi square test. MC: Monte Carlo. $\quad$ FE: Fisher Exact

$p: p$-value for comparing between the studied groups.

p1: $p$-value for comparing between misoprostol and diclofenac.

$p 2: p$-value for comparing between misoprostol and misoprostol diclofenac.

p3: $p$-value for comparing between misoprostol and placebo.

p4: $p$-value for comparing between diclofenac and misoprostol diclofenac.

p5: $p$-value for comparing between diclofenac and placebo.

6: $p$-value for comparing between misoprostol diclofenac and placebo.

*: Statistically significant at $p \leq 0.05$.

\section{Discussion}

Intrauterine implant (IUD) is one of the most powerful types of contraceptive available in addition to one of the best long-acting reversible contraception (LARC) [1] . Its efficacy applies to its low rate of unintended conception, which is anticipated due to the independent utilisation of adult females [8].

Misoprostol is a low-cost prostaglandin E analogue that has been successfully utilised for cervical maturation and dilatation prior to minimally intrusive gynaecological procedures; for evacuation and hysteroscopy or for the surgical termination of miscarriage. Given insufficient evidence to justify its application, misoprostol is mostly used by physicians prior to IUD insertion [9]

Diclofenac is a non-steroidal anti-inflammatory drug (NSAID) used to relieve inflammation and to reduce discomfort in some conditions [10].

The purpose of this research was to determine the effectiveness of the combination of vaginal misoprostol and intramuscular diclofenac sodium in the reduction of pain and to promote IUD penetration in women with cervical stenosis.

In the current work, we found that there was no significant association between four classes in terms of age, BMI, success in severity, mode of delivery and history of genital infection, number of prior abortions, time of last delivery, uterine location and uterine duration. These results are in line with those of several other authors [11].
In this analysis, we observed that the misoprostol group and the misoprostol diclofenac group showed a significantly higher amount of simple IUD insertion, and the misoprostol diclofenac group showed a significantly lower, incredibly difficult insertion compared to other groups ( $p$ value 0.070). In compliance with our finding, Abo Gharam et al., 2019 found that 400 micrograms of misoprostol were vaginally 2 hours before facilitates its insertion in comparison to IM administration of $75 \mathrm{mg}$ ofdiclofenac sodium, 2-hours before IUCD insertion, and also Mohammed et al., 2018. It has been observed that 400 micrograms of sublingual misoprostol 2 hours before IUCD injection decreases the amount of missed insertion and discomfort during insertion [11,12]. In comparison to our results, Dijkhuizen et al., 2011 found that there was no advantage to misoprostol prior to IUD insertion. There is, however, a tendency for potential exposure to side-effects. In addition, Heikinheimo et al., 2010 also found this sublingual misoprostol did not have a significant effect on the ease of insertion in subjects having repeat insertion of the LNG-IUS [13,14]

Dijkhuizen et al., 2011 The study did not indicate a beneficial effect of misoprostol administration. Misoprostol can have an effect on cervical dilation; however, this may not result in smoother injection or better pain scores. IUD injection in nulliparous women using 400 micrograms misoprostol and 100mg diclofenac was slightly better than in women using $100 \mathrm{mg}$ diclofenac alone $(1 \mathrm{~h}$ prior to IUD inserts). However, no difference in dilatation of the cervix, as well aspatient-scored 
pain estimation and the number of failed insertionswas observed between the two groups [11]

Gemzell-Danielsson et al., 2013 Non-steroidal anti-inflammatory agents (NSAIDs) have been documented to be useful in the reactive treatment of post-insertion pain, although no prophylactic advantage has been identified. The NSAID controls prostaglandin-mediated side effects (e.g. Uterine cramping). If preferential use of misoprostol plays a part in the treatment of pain in some subsets of women (e.g. nulliparous women and insertion nonroutine/difficult) has yet to be adequately studied [15].

In the current research, we found that there was a statistically important difference between misoprostol diclofenac and placebo groups with respect to pain, and our study indicates that $75 \mathrm{mg}$ of diclofenac sodium intramuscularly administered 2 hours before IUCD injection decreases pain sensations during IUD insertion relative to other groups ( $p$-value 0.164$)$.

In an analysis of Fouda et al., 2016 A statistically meaningful drop in pain scores with diclofenac potassium and lidocaine gel pretreatment was observed in parous women with copper IUD, the reduction of which is not clinically important. These results could be more applicable to nulliparous women who feel more pain than parous women with IUD insertion help studies of diclofenac potassium and lidocaine gel in this population [16]

None of the other RCTs indicated a decrease in the patient reported discomfort when misoprostol was used for cervical priming prior to IUD insertion. While there was difference between the route trials (vaginal or oral) and the timing (90 minutes to 4 hours) of misoprostol administration, the dosage $(400 \mathrm{mcg})$ was the same in each sample and the overall results are clear. In comparison to that, in all eight RCTs, premedication with misoprostol was associated with an increase in side effects [17]

Espey et al., 2014 It was observed that $400 \mathrm{mcg}$ of buccal misoprostol 2-8 hours before IUD in nulliparous women did not alleviate discomfort or increase the ease of IUD insertion. Most women were able to wait for pain-reducing medications, suggesting the need to seek options for pain relief through IUD insertion [18].

Abo Gharam et al., 2019 found that there was an insignificant difference between misoprostol and diclofenac groups as regards to pain score. [11]. In the current survey, we found that side effects in IUD insertion were nausea and vomiting at 37.5 per cent and syncopal attack at 6.3 per cent in the misoprostol group, gastritis at 18.7 per cent in the diclofenac group, nausea and vomiting at 18.7 per cent, syncopal attack at 6.3 per cent, and gastritis at 12.5 per cent in the misoprostol diclofenac group. In line with our outcome.

Abo Gharam et al., 2019 found that side effects in IUD insertion were nausea and vomiting in $36.7 \%$ and syncopal attack in $3.3 \%$ in the misoprostol group in the diclofenac group only gastritis in $20 \%$ of patients [11].

In a study by Espey et al., 2014 There were no variations within groups with regard to signs of nausea, vomiting, or diarrhea [18]. Inconsistent with our outcome Maged et al., 2018 found that more women encountered nausea, vomiting, and cramps in the misoprostol community than in the placebo group. The disparity was statistically important, however, only in women who suffered cramping [19].

Dijkhuizen et al., 2011 It has been shown that severe complications such as perforation or major bleeding have not occurred. Vasovagal-like symptoms, such as dizziness, nausea and vomiting, resulted in 20 participants in misoprostol and 15 in the placebo group. Syncope was identified in three participants in the misoprostol group compared to two participants in the placebo group [13]

Cramping in the abdomen was the most common side-effect ( 38.2 percent). Fever (temperature $>38$. 08C) did not exist in the misoprostol group, although 3.3 per cent of patients in the placebo group experienced fever. Other side effects included itching, exanthema, sweating, dysuria and paresthesia did not vary between groups (P 1/4 0.48) [19]

Swenson et al., 2012 Studied nulliparous women seeking either T380A copper or IUD levonorgestrel were randomised to either $400 \mathrm{mg}$ misoprostol or placebo (vaginally or buccally) 3-4 hours prior to IUD insertion. The primary outcome was that healthcare offered perceived ease of insertion reported on a visual analogue scale (anchors: 0 extremely easy, 100 impossible). Patients have completed Questionnaires discussing discomfort using a validated visual analogue scale (anchor: 0 zero, 100 worst imaginable) before injection shortly following insertion and before hospital discharge. They find that self-administration of misoprostol prior to IUD injection does not relieve IUD insertion or reduce pain endured by patients in nulliparous women [20]. 


\section{Conclusion:}

Vaginal misoprostol and intramuscular diclofenac sodium administration prior to IUCD injection in women with cervical stenosis promote IUCD insertion, decrease insertion failure and minimise pain sensitivity during IUCD insertion.

\section{Compliance with ethical standards:}

\section{Disclosure statement:}

No potential conflict of interest was reported by the authors.

Informed consent: Informed consent was obtained from all participants in the study.

Ethical approval: All procedures performed in studies were approved with ethical standards of the Ethical Committee of The Department of Obstetrics and Gynecology Faculty of Medicine, Zagazig University.

Funding: No funding was taken from agencies in the public, commercial, or not-for-profit sectors

\section{Acknowledgements:}

Special thanks to the patients and their families for their support of our work. Also, the authors appreciate the support from ultrasound staff of Zagazig University outpatient clinic for the outstanding support during the entire study.

\section{References}

1- WINNER B., PEIPERT J.F., ZHAO Q., BUCKEL C., MADDEN T., ALLSWORTH J.E. and SECURA G.M.: "Effectiveness of Long-Acting Reversible Contraception". New England Journal of Medicine, 366 (21): 1998-2007, 2012.

2- MORAMAZI F., ROOHIPOOR M. and NAJAFIAN M.: Association between internal cervical os stenosis and other female infertility risk factors. Middle East Fertility Society Journal, 23 (4): 297-299, 2018.

3- LI Y.T., KUO T.C., KUAN L.C. and CHU Y.C.: Cervical softening with vaginal misoprostol before intrauterine device insertion. International Journal of Gynecology \& Obstetrics, 89 (1): 67-68, 2005.

4- NZEWI C.: Oral versus self-administered vaginal misoprostol at home before surgical termination of pregnancy by Oppegaardetal.BJOG: An International Journal of Obstetrics \& Gynaecology, 113 (8): 979980-979984, 2006.

5- LIVSHITS A. and SEIDMAN D.S.: Role of non-steroidal anti-inflammatory drugs in gynecology. Pharmaceuticals, 3 (7): 2082-2089, 2010.

6- HAWKER G.A., MIAN S., KENDZERSKA T. and FRENCH M.: Measures of adult pain: Visual analog scale for pain (vas pain), numeric rating scale for pain (nrs pain), mcgill pain questionnaire (mpq), short-form mcgill pain questionnaire (sf-mpq), chronic pain grade scale (cpgs), short form-36 bodily pain scale (sf-36 bps), and measure of intermittent and constant osteoarthritis pain (icoap). Arthritis care \& research, 63 (S11): S240-S252, 2011.

7- OKITSU H., SAWAMURA J., NISHIMURA K., SATO Y. and ISHIGOOKA J.: A comparison of a patient-rated visual analogue scale with the Liebowitz Social Anxiety Scale for social anxiety disorder: A cross-sectional study. Open Journal of Psychiatry, 2014.

8- American College of Obstetricians and Gynecologists: Increasing use of contraceptive implants and intrauterine devices to reduce unintended pregnancy. ACOG Committee Opinion No. 450. Obstet. Gynecol., 114 (6): 1434 1438, 2009.

9- KHALAF M., AMIN A.F., SAYED Z., EL-NASHAR I.M and ABBAS A.M.: A randomized double-blind controlled trial of two different doses of self-administered vaginal misoprostol for successful copper intrauterine device insertion. Middle East Fertility Society Journal, 22 (4): 264-268, 2017.

10- ALTMAN R., BOSCH B., BRUNE K., PATRIGNANI P. and YOUNG C.: Advances in NSAID development: Evolution of diclofenac products using pharmaceutical technology. Drugs, 75 (8): 859-877, 2015.

11- ABO GHARAM M.A., FARAHAT M.A., EL-AHWAL L.M. and EL-GHARIB M.N.: Effect of diclofenac versus misoprostol on pain perception during copper iud insertion in cases of stenosed cervix. Gyne. and Obste. Open A Open J., 17-21, 2019.

12- MOHAMMED M.A., SELEEM K.S., SADEK A.M. and NADA A.I.Z.: Sublingual misoprostol before insertion of an intrauterine device. Benha Medical Journal, 35 (1): 104, 2018

13-DIJKHUIZEN K., DEKKERS O.M., HOLLEBOOM C.A., DE GROOT C.J., HELLEBREKERS B.W., VAN ROOSMALEN G.J. and HELMERHORST F.M.: Vaginal misoprostol prior to insertion of an intrauterine device: An RCT. Human Reproduction, 26 (2): 323-329, 2011.

14- HEIKINHEIMO O., INKI P., KUNZ M., PARMHED S., ANTTILA A. M., OLSSON S.E. and GEMZELLDANIELSSON K.: Double-blind, randomized, placebocontrolled study on the effect of misoprostol on ease of consecutive insertion of the levonorgestrel-re leasing intrauterine system. Contraception, 81 (6): 481-486, 2010.

15- GEMZELL-DANIELSSON K., MANSOUR D., FIALA C., KAUNITZ A.M. and BAHAMONDES L.: Management of pain associated with the insertion of intrauterine contraceptives. Human reproduction update, 19 (4): 419427, 2013.

16- FOUDA U.M., ELDIN N.M.S., ELSETOHY K.A., TOLBA H.A., SHABAN M.M. and SOBH S.M.: Diclofenac plus lidocaine gel for pain relief during intrauterine device insertion. A randomized, double-blinded, placebo-controlled study. Contraception, 93 (6): 513-518, 2016.

17- SCAVUZZI A., SOUZA A.S., COSTA A.A. and AMORIM M.M.: Misoprostol prior to inserting an intrauterine device in nulligravidas: A randomized clinical trial. Human Reproduction, 28 (8): 2118-2125, 2013.

18- ESPEY E., SINGH R.H., LEEMAN L., OGBURN T., FOWLER K. and GREENE H.: Misoprostol for intrauterine device insertion in nulliparous women: A randomized 
controlled trial. American Journal of Obstetrics and Gynecology, 210 (3): 208-e1, 2014.

19- MAGED A.M., YOUSSEF G., ELDALY A., OMRAN E., EL NAGGAR M., ABDEL HAK A. and OGILA A.I.:
Benefits of vaginal misoprostol prior to IUD insertion in women with previous caesarean delivery: A randomised controlled trial. The European Journal of Contraception \& Reproductive Health Care, 23(1): 32-37, 2018.

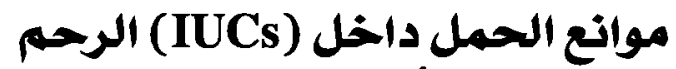 هى واحلدة من أقوى وسائل منـع الحمل (الرحل}

ونظام افراز الليفونود جستريل داخل الرحم (LNG-IUS 380A (Cu-IUD) العالم وكلا النموذجين معتدلى التكفة وآمنان وفعالان على المدي الطنى الطويل.

كان الهدف من هذه الدراسة: هو تقييم فعالية توليفة الميزبيربستل الههبلى مع ديكلوفيناك الصوديوم العضلى فى تقليل الألم وتسهيل

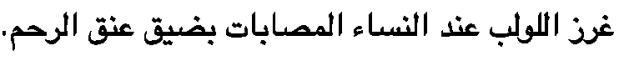

تم تقسيم المرضى عشوائياً إلى أريع مجموعات (17 مريضة لكل مجموعة) بأستخدام التوزيع العشوائى البسيط وصنفوا إلى: - المجموعة الأولى (مجموعة ميسوبروستول): تثمل بـ مريضة تلقوا حبتين ( . ع مجم) من الميزويروستول فى المهبل قبل ساعتين من إدخال اللولب.

- المجموعة الثانية (مجموعة ديكلوفيناك): يشمل rT مريضة تلقوا ديكلفيناك الصوديوم Vo مجم أمبولة فى العضل قبل ساعثين من إخخال اللولب.

- المجموعة الثالثة (مجموعة ميسويروستول ديكلوفيناك): تشمل بr مريضة تناولوا قرصين (.. ع مجم) من الميزويروستول فى المهبل وديكوفيناك الصوديوم Vo مجم أمبولة في العضل قبل سعاعتين من إدخال اللولب. - المجموعة الرابعة (المجموعة الضابطة) تشمل بس مريضة تلقوا علاج وهمى. النتيجة: أظهرت مجموعة الميزويروستول ومجموعة الميزوبروستول ديكلوفيناك سهولة فى تركيب IUD بفارق معنوى واضح، وأظهرت

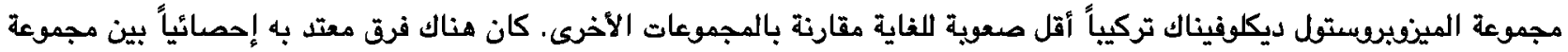
الميزوبروستول ديكوفيناك ومجموعة الدواء الوهمى فيما يتعلق بالألم.

الاستتاج: إن إعطاء الميزوبروستول المهبلى وديكوفيناك الصوديوم فى العضل قبل إدخال IUCD فى النساء المصابات بضيق عنق الرحم

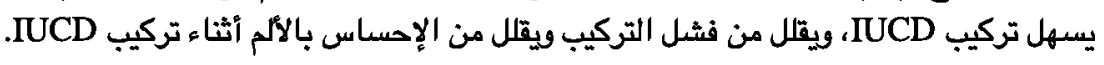

